\title{
Correction: Lobular intraepithelial neoplasia arising within breast fibroadenoma
}

\author{
Gennaro Limite ${ }^{1}$, Emanuela Esposito ${ }^{1 *}$, Viviana Sollazzo ${ }^{1}$, Giuseppe Ciancia ${ }^{2}$, Cesare Formisano ${ }^{1}$, Rosa Di Micco ${ }^{1}$, \\ Dario De Rosa ${ }^{3}$ and Pietro Forestieri ${ }^{1}$
}

After publication of our article [1], it has come to our attention that Professor Cesare Formisano was incorrectly excluded from the list of authors in the initial version of this manuscript. We publish this correction to update the author list to include Professor Formisano as an author. The correct author list is as follows:.

Gennaro Limite, Emanuela Esposito, Viviana Sollazzo, Giuseppe Ciancia, Cesare Formisano, Rosa Di Micco, Dario De Rosa and Pietro Forestieri.

We apologise for any inconvenience caused by this error.

\section{Author details \\ 'University Department of Clinical Medicine and Surgery, Breast Unit, University of Naples Federico II, Naples, Italy. ${ }^{2}$ Department of Pathology, University of Naples Federico II, Naples, Italy. ${ }^{3}$ Department of Diagnostic Radiology, University of Naples Federico II, Naples, Italy.}

Received: 26 March 2014 Accepted: 26 March 2014

Published: 1 April 2014

\section{Reference}

1. Limite G, Esposito E, Sollazzo V, Ciancia G, Di Micco R, De Rosa D, Forestieri P: Lobular intraepithelial neoplasia arising within breast fibroadenoma. BMC Res Notes 2013, 6:267.

\footnotetext{
* Correspondence: emanuelaexpo@hotmail.it

'University Department of Clinical Medicine and Surgery, Breast Unit, University of Naples Federico II, Naples, Italy

Full list of author information is available at the end of the article
}

\section{Submit your next manuscript to BioMed Central and take full advantage of:}

- Convenient online submission

- Thorough peer review

- No space constraints or color figure charges

- Immediate publication on acceptance

- Inclusion in PubMed, CAS, Scopus and Google Scholar

- Research which is freely available for redistribution 